\title{
Multiple Variations of Extensor Muscles of Forearm in Relation to the Radial Nerve: a Case Report and Review
}

\author{
Múltiples Variaciones de los Músculos Extensores del Antebrazo \\ en Relación con el Nervio Radial: Reporte de Caso y Revisión
}

"Prakash; "Rajalakshmi Rai; *Anu Vinod Ranade; "Latha V Prabhu; "Mangala M Pai \& **Gajendra Singh

PRAKASH; RAI, R; RANADE, A. V.; PRABHU, L. V.; PAI, M. M. \& SINGH, G. Multiple variations of extensor muscles of forearm in relation to the radial nerve: a case report and review. Int. J. Morphol., 26(2):447-449, 2008.

SUMMARY: During routine dissection in the Department of Anatomy, multiple variations of forearm muscles in relation to the radial nerve and its branches were observed on the right side of a 34 year old male cadaver. Brachioradialis close to its origin was receiving muscle fibers from the brachialis and the radial nerve was passing in between them. Extensor carpi radialis brevis was absent and the extensor carpi radialis longus was giving two tendons in the second compartment of extensor retinaculum before its insertion while passing deep to the abductor pollicis longus. Absence of extensor carpi radialis brevis can be explained with the arrangement in lower mammals, where the two extensores carpi radiales are represented by one muscle. Ontogeny repeats phylogeny and anatomical variations have developmental basis. Hence, the pattern of muscular arrangement in this case can be said to be less evolved than the usual arrangement. The course of radial nerve between the two heads of brachioradialis makes it highly vulnerable to compression and injury, which may manifest as wrist drop (radial nerve palsy) or radial tunnel syndrome (compression of posterior interosseous nerve). dial nerve.

KEY WORDS: Anatomical variations; Development; Extensor carpi radialis longus and brevis muscles; Forearm; Ra-

\section{INTRODUCTION}

Marked variations from the normal are rarely seen in superficial group of extensors (Hollinshead, 1969). Occasionally, aberrant muscle slips are present among the superficial group of extensors (Hollinshead). The course of radial nerve in the lower part of arm lies between the brachialis and the brachioradialis and extensor carpi radialis longus muscles and this position gives off the nerves to these muscles (Anson \& McVay, 1971; Hollinshead). The radial tunnel is described as a $5-\mathrm{cm}$ long furrow bounded by brachialis and the biceps tendon medially and the mobile extensor muscles anterolaterally, beginning just proximal to the radiocapitellar joint and ending at the distal edge of supinator. After the point of bifurcation of the radial nerve, the posterior interosseous nerve (PIN) travels through the radial tunnel (Loh et al., 2004). Prasartritha et al. (1993) dissected sixty fresh cadaveric upper extremities and suggested the course of the radial nerve in the radial tunnel, an area that varies but begins in the furrow between the brachioradialis and brachialis in the distal arm and ends at the distal edge of the supinator muscle in the proximal forearm. Ferdinand et al. (2006) concluded that the most common MRI (magnetic resonance imaging) finding in radial tunnel syndrome are muscle denervation edema or atrophy along the distribution of the PIN.

\section{CASE REPORT}

The following variations were observed on the right side during routine dissection in an adult 34 year old male cadaver. Brachialis was giving additional head of origin for brachioradialis close to its bony origin from humerus; thus making the radial nerve more vulnerable to compression proximal to and through its course in the radial tunnel (Fig. 1). Extensor carpi radialis brevis (ECRB) was absent, whereas extensor carpi radialis longus (ECRL) was giving two tendons in the second compartment of extensor retinaculum before its insertion while passing deep to the abductor pollicis longus (Fig. 2).

\footnotetext{
* Department of Anatomy, C.B.S., Kasturba Medical College, Bejai, Mangalore, Karnataka, INDIA, Pin: 575004.

** Department of Anatomy, Institute of Medical Sciences, Banaras Hindu University, Varanasi, U.P., INDIA, Pin: 221005.
} 

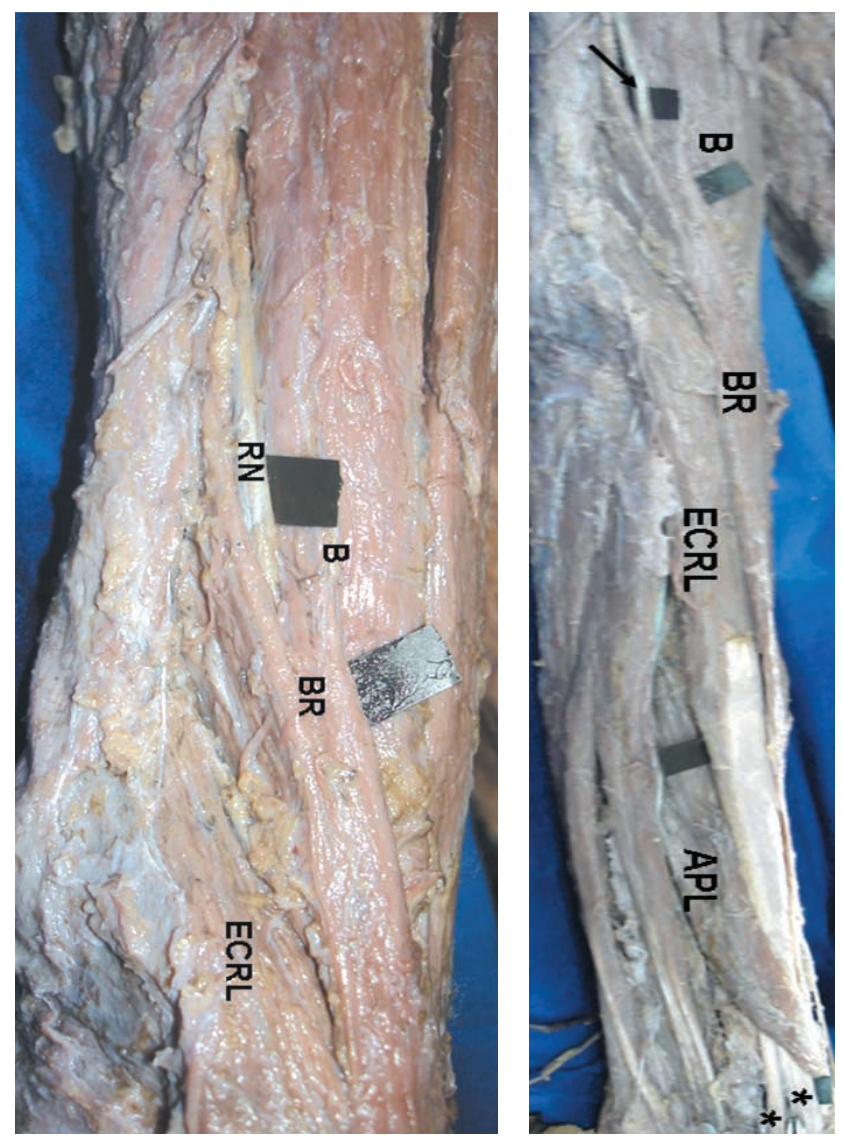

Fig. 1. RN. Radial nerve; B. Brachialis muscle; BR. Brachioradialis muscle; ECRL. Extensor carpi radialis longus muscle.

Fig. 2. Arrow: Radial nerve; B. Brachialis muscle; BR. Brachioradialis muscle; ECRL. Extensor carpi radialis longus muscle; APL. Abductor pollicis longus muscle; Stars: Tendons of extensor carpi radialis longus muscle.

\section{DISCUSSION}

While dissecting the body of an 80-year-old female Claassen \& Wree (2002) described variation of ECRL, which gave origin to an accessory head. The tendon of this accessory head passed through a separate tunnel in the extensor retinaculum and inserted in the middle of the first metacarpal bone (Claassen \& Wree). On the contrary in the present case ECRL was passing as two tendons in the second compartment of extensor retinaculum before its insertion. Caetano et al. (2004) analyzed the anatomical variations of the ECRL and ECRB in sixty male adults cadaver upper limbs and reported that the supernumerary tendons were found in 3 hands (all in relation to the ECRL tendon), whereas the presence of an accessory tendon making the union between the tendons of ECRL and ECRB was registered in 4 dissected hands
(Caetano et al.). Whereas in the present case, the ECRL received an additional head of origin from brachialis and divided into two tendons before insertion.

Sixty upper limbs from 30 Turkish subjects (18 males and 12 females) were dissected to reveal the course of the PIN and to examine possible compression sites at the proximal and distal edges of the supinator muscle, and the exit of the nerve from the ECRB (Kirici \& Irmak, 2004). An anatomic study of 45 supper limbs, from 40 cadavers, was performed to analyse the relations between the medial edge of the ECRB and the PIN and Laulan et al. (1994) suggested that the ECRB is a possible cause of PIN entrapment. Hence, the absence of ECRB in our case further increased the chances of PIN entrapment

Embryological hypothesis and phylogenic correlation: In lower mammals the two extensores carpi radiales are represented by one muscle (Bergman et al., 1988). Anatomical variations always have underlying cause as developmental arrest in the different stages of gestation. Ontogeny repeats phylogeny hence, the pattern of muscular arrangement in this case can be said to be less evolved than the usual arrangement.

PRAKASH; RAI, R; RANADE, A. V.; PRABHU, L. V.; PAI, M. M. \& SINGH, G. Múltiples variaciones de los músculos extensores del antebrazo en relación con el nervio radial: Reporte de caso y revisión. Int. J. Morphol., 26(2):447-449, 2008.

RESUMEN: Durante una disección de rutina en el Departamento de Anatomía, se observaron múltiples variaciones de los músculos del antebrazo, en relación con el nervio radial y sus ramos, en el lado derecho de un cadáver de 34 años de edad, de sexo masculino. Cerca de su origen el músculo braquioradial recibía fibras del músculo braquial y el nervio radial cruzaba entre ellos. El músculo extensor radial corto del carpo se encontraba ausente y el músculo extensor radial largo del carpo se continuaba con dos tendones en el segundo compartimiento del retináculo extensor, bajo el músculo abductor largo de pulgar, antes de su inserción. La ausencia del músculo extensor radial corto del carpo se puede explicar en mamíferos inferiores, donde los dos músculos extensores radiales están representados por un sólo músculo. La ontogenia repite la filogenia y las variaciones anatómicas inciden en su desarrollo. Por lo tanto, de acuerdo al patrón muscular se puede afirmar que en este caso existe menos evolución que lo habitual. El curso del nervio radial entre las dos cabezas del músculo braquioradial, lo hace muy vulnerable a la compresión y las lesiones, que pueden manifestarse son, caída de la muñeca (parálisis del nervio radial) o el síndrome del túnel radial (compresión del nervio interóseo posterior).

PALABRAS CLAVE: Variación anatómica; Desarrollo; Músculos extensores radiales largo y corto; Antebrazo; Nervio radial. 
PRAKASH; RAI, R; RANADE, A. V.; PRABHU, L. V.; PAI, M. M. \& SINGH, G. Multiple variations of extensor muscles of forearm in relation to the radial nerve: a case report and review. Int. J. Morphol., 26(2):447-449, 2008.

\section{REFERENCES}

Anson, B. J. \& McVay, C. B. Surgical Anatomy. $5^{\text {th }}$ ed. W.B. Saunders Company, Philadelphia, 1971. pp.1012-7.

Bergman, R. A.; Thompson, S. A.; Afifi, A. K. \& Saddeh, F. A. Copendium of Human Anatomical Variation. Urban and Schwarzenburg, Baltimore, 1988. pp.138-9.

Caetano, F. M.; Albertoni, M. W.; Caetano, B. E. \& Pérez, M. R. Anatomical study of insertions of the extensor carpi radialis longus and brevis. Int. J. Morphol., 22(4):245$51,2004$.

Claassen, H. \& Wree, A. Multiple variations in the region of Mm. extensores carpi radialis longus and brevis. Ann. Anat., 184:489-91, 2002.

Ferdinand, B. D.; Rosenberg, Z. S.; Schweitzer, M. E.; Stuchin, S. A.; Jazrawi, L. M.; Lenzo, S. R.; Meislin, R. J. \& Kiprovski, K. MR imaging features of radial tunnel syndrome: initial experience. Radiology, 240:161-8, 2006.

Hollinshead, W. H. Anatomy for Surgeons. The Back and Limbs. Vol 3. $2^{\text {nd }}$ Ed. Harper and Row Publishers, Newyork, 1969. pp.428-41.

Kirici, Y. \& Irmak, M. K. Investigation of two possible compression sites of the deep branch of the radial nerve and nerve supply of the extensor carpi radialis brevis muscle. Neurol. Med. Chir. (Tokyo), 44:14-9, 2004.

Laulan, J.; Daaboul, J.; Fassio, E. \& Favard, L. The relation of the short radial extensor muscle of the wrist with the deep branch division of the radial nerve. Its significance in the physiopathology of elbow pain. Ann. Chir. Main Memb. Super., 13:366-72, 1994.

Loh, Y. C.; Lam, W. L.; Stanley, J. K. \& Soames, R. W. A new clinical test for radial tunnel syndrome-the Ruleof-Nine test: A cadaveric study. J. Orthop. Surg. (Hong Kong), 12(1):83-6, 2004.

Prasartritha, T.; Liupolvanish, P. \& Rojanakit, A. A study of the posterior interosseous nerve (PIN) and the radial tunnel in 30 Thai cadavers. J. Hand Surg. [Am], 18:10712, 1993.

\section{Correspondence to: \\ Dr. Prakash \\ Department of Anatomy \\ Centre for Basic Sciences \\ Kasturba Medical College \\ Pin: 575004 \\ Bejai, Mangalore, Karnataka \\ INDIA.}

Phone: 919342321730,918242211746 (Off.)

Fax: 918242428183

Email: prakashrinku@rediffmail.com

Received: 01-02-2007

Accepted: 12-09-2007 
